\title{
Electrochemical Regeneration of Spent Alkaline Absorbent from Direct Air Capture
}

\author{
Qingdian Shu, Louis Legrand, Philipp Kuntke,* Michele Tedesco, and Hubertus V. M. Hamelers
}

Cite This: Environ. Sci. Technol. 2020, 54, 8990-8998

Read Online

ABSTRACT: $\mathrm{CO}_{2}$ capture from the atmosphere (or direct air capture) is widely recognized as a promising solution to reach negative emissions, and technologies using alkaline solutions as absorbent have already been demonstrated on a full scale. In the conventional temperature swing process, the subsequent regeneration of the alkaline solution is highly energy-demanding. In this study, we experimentally demonstrate simultaneous solvent regeneration and $\mathrm{CO}_{2}$ desorption in a continuous system using a $\mathrm{H}_{2}$-recycling electrochemical cell. A pH gradient is created in the electrochemical cell so that $\mathrm{CO}_{2}$ is desorbed at a low $\mathrm{pH}$, while an alkaline capture solution $(\mathrm{NaOH})$ is regenerated at high $\mathrm{pH}$. By testing the cell under different working conditions, we experimentally achieved $\mathrm{CO}_{2}$ desorption with an energy consumption of

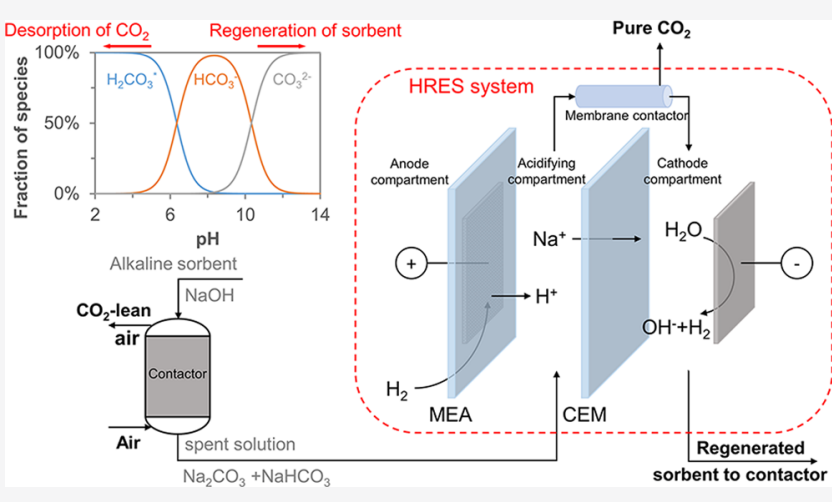
$374 \mathrm{~kJ} \cdot \mathrm{mol}^{-1} \mathrm{CO}_{2}$ and a $\mathrm{CO}_{2}$ purity higher than $95 \%$. Moreover, our theoretical calculations show that a minimum energy consumption of $164 \mathrm{~kJ} \cdot \mathrm{mol}^{-1} \mathrm{CO}_{2}$ could be achieved. Overall, the $\mathrm{H}_{2}$-recycling electrochemical cell allowed us to accomplish the simultaneous desorption of high-purity $\mathrm{CO}_{2}$ stream and regeneration of up to $59 \%$ of the $\mathrm{CO}_{2}$ capture capacity of the absorbent. These results are promising toward the upscaling of an energy-effective process for direct air capture.

\section{INTRODUCTION}

Climate change is one of the most critical global challenges nowadays. Increasing atmospheric $\mathrm{CO}_{2}$ concentration brought by anthropogenic emissions has been recognized as the primary driver of global warming. ${ }^{1-5}$ The global average surface temperature has risen by $0.85{ }^{\circ} \mathrm{C}$ in the period from 1880 to 2012 , and over $85 \%$ of this temperature rise occurred in the past century can be attributed to industrialization. ${ }^{6}$ Besides, most of the $\mathrm{CO}_{2}$ in the atmosphere will ultimately be absorbed by the oceans causing ocean acidification, which has been proved harmful to marine organisms. ${ }^{7}$ The ocean $\mathrm{pH}$ has been already reduced by 0.1 units compared to the preindustrial level, ${ }^{8}$ and it could eventually be 0.7 units lower with continuous emission of $\mathrm{CO}_{2}$ from the combustion of fossil fuels. ${ }^{9}$

In this context, it has been widely recognized that capturing $\mathrm{CO}_{2}$ from emission points and even directly from the air provides a potential solution to mitigate $\mathrm{CO}_{2}$ emissions and ultimately reduce the atmospheric $\mathrm{CO}_{2}$ concentration. ${ }^{10,11}$ In particular, direct air capture (DAC) technologies aim to extract $\mathrm{CO}_{2}$ directly from ambient air and hence offer the possibility to achieve $\mathrm{CO}_{2}$ capture from distributed sources. ${ }^{12-14}$ Therefore, DAC is not restricted by location as conventional carbon capture technologies that are designed to be coupled with large $\mathrm{CO}_{2}$ emission points. The thermodynamic minimum energy requirement for DAC is relatively higher compared to carbon capture from flue gas, due to the low $\mathrm{CO}_{2}$ concentration in air. ${ }^{13}$ Nonetheless, further studies on DAC are essential for reducing climate risks.

Various technologies have been proposed for DAC, ${ }^{14-16}$ and one of the most extensively studied approaches is wet scrubbing with alkaline hydroxide solutions (typically $\mathrm{NaOH}$ or $\mathrm{KOH}) .{ }^{16-18}$ When air is in contact with an alkaline solution (e.g., $\mathrm{NaOH}), \mathrm{CO}_{2}$ is absorbed, and a sodium carbonate solution is produced according to the reaction ${ }^{14}$

$$
\begin{aligned}
2 \mathrm{NaOH}+\mathrm{CO}_{2} \rightarrow & \mathrm{Na}_{2} \mathrm{CO}_{3}+\mathrm{H}_{2} \mathrm{O} \\
& \Delta H^{0}=-109.4 \mathrm{~kJ} \cdot \mathrm{mol}^{-1}
\end{aligned}
$$

Conventionally, the sorbent $(\mathrm{NaOH})$ is regenerated by exchanging sodium and calcium ions by dosing calcium hydroxide. Subsequently, the resulting calcite $\left(\mathrm{CaCO}_{3}\right)$ precipitate is thermally treated at $700{ }^{\circ} \mathrm{C}$ to produce $\mathrm{CO}_{2}$ and calcium oxide. Finally, calcium hydroxide can be regenerated by rehydration of calcium oxide.

Received: March 30, 2020

Revised: June 24, 2020

Accepted: June 25, 2020

Published: June 25, 2020 


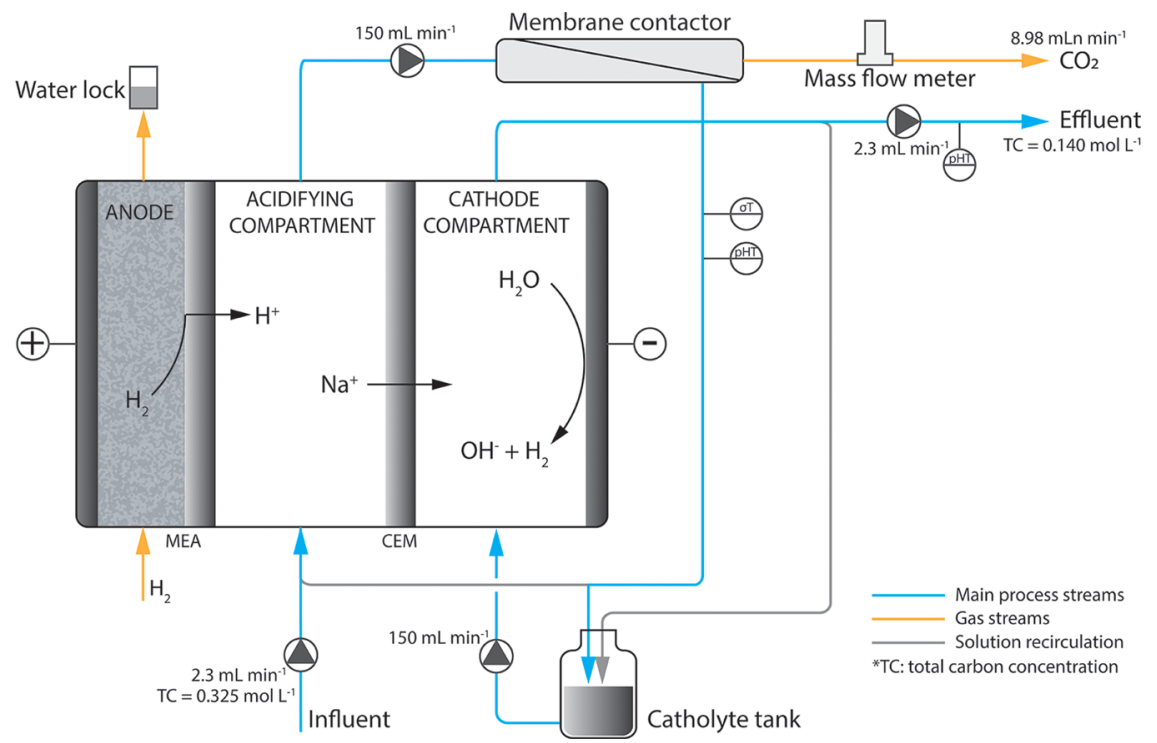

Figure 1. Schematic drawing of the experimental setup. The values indicated in the figure are from one of the experiments performed in this work.

Since the chemical reaction between $\mathrm{NaOH}$ and $\mathrm{CO}_{2}$ is spontaneous, the regeneration of the alkaline sorbent (coupled with desorption of $\mathrm{CO}_{2}$ gas) consumes the largest fraction of energy in the conventional wet scrubbing process (i.e., a minimum of $179 \mathrm{~kJ} \cdot \mathrm{mol}^{-1} \mathrm{CO}_{2}$ at standard temperature and pressure $\left.^{18,19}\right)$. Alternative regeneration processes have been developed to reduce energy consumption. For instance, Mahmoudkhani and Keith proposed a titanate cycle that halved the energy requirements compared to the conventional regeneration process, ${ }^{18}$ while $\mathrm{Kim}$ et al. suggested an electrochemical method for the regeneration of $\mathrm{LiOH}$ from used $\mathrm{CO}_{2}$ adsorbents. ${ }^{20}$ The use of electrochemical systems as the $\mathrm{CO}_{2}$ desorption step includes a number of advantages such as (i) potentially low energy consumption (since the process occurs at room temperature), (ii) better operational control (by exploiting the electric field), and (iii) easy integration with renewable energy sources (since the process requires only electricity as energy input). ${ }^{21-28}$

In this work, we developed an electrochemical process for regenerating the alkaline solution in the wet scrubbing process for DAC application; meanwhile, high-purity $\mathrm{CO}_{2}$ gas stream could be produced that is suitable for storage or utilization. The process is based on a $\mathrm{H}_{2}$-recycling electrochemical system (HRES) coupled to a membrane contactor that was originally developed for nitrogen recovery from wastewater. ${ }^{2,30}$ In HRES, alkaline and acidic conditions are created in two adjacent compartments, respectively. Additionally, $\mathrm{CO}_{2}$ equilibria are highly dependent on the $\mathrm{pH}$ of the solution (eqs 2-4, values taken from refs 31, 32). Accordingly, we adapted the system operation for DAC application. The electrochemical cell consisted of three compartments, i.e., an anode compartment, an "acidifying" compartment, and a cathode compartment. During the operation, protons $\left(\mathrm{H}^{+}\right)$ produced from the $\mathrm{H}_{2}$ oxidation at the anode are transported to the acidifying compartment where the spent solution coming from the air contactor is fed. The decreasing $\mathrm{pH}$ of the acidifying solution leads to the conversion of (bi)carbonate ions to carbonic acid (eqs 2 and 3 ). When the solution is saturated in carbonic acid $\left(\mathrm{H}_{2} \mathrm{CO}_{3}{ }^{*}\right.$, including dissolved $\left.\mathrm{CO}_{2}\right)$, a further $\mathrm{pH}$ decrease leads to the desorption of $\mathrm{CO}_{2}$ gas (eq 4). The oversaturation point is determined by the $\mathrm{CO}_{2}$ partial pressure in the membrane contactor. Meanwhile, $\mathrm{NaOH}$ is regenerated in the cathode due to the production of hydroxides $\left(\mathrm{OH}^{-}\right)$and can be reused as a DAC absorbent.

$$
\begin{aligned}
& \mathrm{HCO}_{3}^{-} \rightleftharpoons \mathrm{CO}_{3}^{2-}+\mathrm{H}^{+} \mathrm{pK} a 2=10.33 \\
& \mathrm{H}_{2} \mathrm{CO}_{3}^{*} \rightleftharpoons \mathrm{HCO}_{3}^{-}+\mathrm{H}^{+} \mathrm{pK} K_{a 1}=6.35 \\
& \mathrm{CO}_{2}+\mathrm{H}_{2} \mathrm{O} \rightleftharpoons \mathrm{H}_{2} \mathrm{CO}_{3}^{*} K_{\mathrm{H}}=0.00339 \mathrm{~mol} \cdot \mathrm{L}^{-1} \cdot \mathrm{atm}^{-1}
\end{aligned}
$$

In this work, we show a proof of principle of such an electrochemical method for $\mathrm{NaOH}$ regeneration and $\mathrm{CO}_{2}$ desorption using an HRES. Different operational conditions were studied to identify suitable conditions to regenerate the absorbent at low energy consumption.

\section{MATERIALS AND METHODS}

2.1. Experimental Methodology. 2.1.1. Experimental Setup. A schematic representation of the experimental setup is shown in Figure 1. The main process streams are the influent flowing into the acidifying compartment and then the membrane contactor, the overflow of excess acidifying solution flowing into the catholyte tank, and the effluent from the cathode compartment. To increase the flow speed inside the cell, two recirculation loops were added for the acidifying and cathode compartments, respectively. The anode was a membrane electrode assembly (MEA) consisting of a $15 \mathrm{~cm}$ $\times 15 \mathrm{~cm}$ Nafion N117 cation exchange membrane (CEM) integrated with a $10 \mathrm{~cm} \times 10 \mathrm{~cm}$ gas diffusion layer (GDL) coated by a Platinum-Vulcan (carbon) catalyst $(0.5 \mathrm{mg} \mathrm{Pt}$. $\mathrm{cm}^{-2}$ ) (FuelCellsEtc, TX). The GDL side of the MEA was facing the anode compartment, while the CEM side was facing the acidifying compartment. The flow channel of the acidifying compartment was created using a polymeric (nitril) spacer (500 $\mu \mathrm{m}$, Sefar, Switzerland). The acidifying compartment and the cathode compartment were separated by a CEM (Nafion N117, $15 \mathrm{~cm} \times 15 \mathrm{~cm}$, FuelCellsEtc, TX). Two Ru/Ir-coated titanium mesh electrodes $(9.8 \mathrm{~cm} \times 9.8 \mathrm{~cm}$, Magneto Special Anodes BV, The Netherlands) were used in the cell, one as cathode and the other one as the current collector for the anode. The whole cell was closed between two poly(methyl 
methacrylate) (PMMA) endplates $(21 \mathrm{~cm} \times 21 \mathrm{~cm} \times 2.5 \mathrm{~cm})$. The HRES produces and consumes $\mathrm{H}_{2}$ at the electrodes; thus, the system can operate without any net $\mathrm{H}_{2}$ consumption by recirculating the $\mathrm{H}_{2}$ from the cathode to the anode. However, to simplify the operation of the system, the $\mathrm{H}_{2}$ feed to the anode compartment was produced by a custom-made electrolyzer. The electrolyzer was operated under constant current conditions and fed with a $25 \mathrm{mM} \mathrm{H}_{2} \mathrm{SO}_{4}$ aqueous solution.

The gas-liquid separation was conducted by a membrane contactor (type MM $1.7 \times 8.75,3 \mathrm{M}$, Germany) whose microporous hollow fiber membrane provided a large surface area for contact between gas and liquid phases. The produced gas first passed through a Nafion tubing (TUB-0003, CO2Meter.com, FL) to remove water vapor. Next, the amount of gas produced was measured by a mass flow meter (ELFLOW Prestige FG-111B, Bronkhorst, The Netherlands). Finally, the gas composition was checked by micro-gas chromatograph (Varian CP-4900, Agilent, CA).

Three peristaltic pumps (Masterflex L/S, Metrohm Applikon BV, The Netherlands) were used in the system, one for the influent, one for the effluent, and one for the recirculation of solution in acidifying and cathode compartments $\left(150 \mathrm{~mL} \cdot \mathrm{min}^{-1}\right)$. The total volume of the acidifying compartment recirculation was $180 \mathrm{~mL}$, including the flow channels of the acidifying compartment $(\sim 5 \mathrm{~mL})$, membrane contactor $(\sim 70 \mathrm{~mL})$, and tubing $(\sim 105 \mathrm{~mL})$. The cathode compartment recirculation had a total volume of $120 \mathrm{~mL}$.

The anode (MEA) potential and cathode potential were measured by two $\mathrm{Ag} / \mathrm{AgCl}$ reference electrodes $(+0.2 \mathrm{~V}$ vs NHE, QM711X, QiS-Prosence BV, The Netherlands) placed at the inlets of the acidifying and cathode compartments, respectively. Two high-impedance preamplifiers (Ext-Ins Technologies, The Netherlands) were connected to the reference electrodes to avoid current leakage. The conductivities of the solutions in the acidifying and cathode compartments were measured using a conductivity sensor (Memosens CLS82D, Endress+Hauser BV, The Netherlands). The $\mathrm{pH}$ of the solution in the acidifying compartment was measured using a $\mathrm{pH}$ sensor (Orbisint CPS11D, Endress+Hauser BV, The Netherlands). A constant current was applied to the electrochemical cell by a power supply (ES 030-5, Delta Elektronika BV, The Netherlands). The $\mathrm{Na}^{+}$concentration in the solution was measured by ion chromatography (761 Compact IC, Metrohm, Switzerland).

2.1.2. Transport of $\mathrm{Na}^{+}$and Definition of $\mathrm{Na}^{+}$Load Ratio. The $\mathrm{Na}^{+}$in the system has mainly two roles: (i) supporting the electrical conductivity in the acidifying compartment and (ii) being transported through the membrane to sustain the ionic current in the cell. The net transport of $\mathrm{Na}^{+}$through the CEM is influenced by several operating conditions, such as the loading rate of $\mathrm{Na}^{+}$in the system (i.e., the molar concentration and flow rate of the influent) and the applied current. Here, we define the " $\mathrm{Na}^{+}$load ratio" $\left(L_{\mathrm{Na}^{+}}\right)$as the ratio between the current density and the $\mathrm{Na}^{+}$loading rate ${ }^{33}$

$$
L_{\mathrm{Na}^{+}}=\frac{j_{\mathrm{c}} \cdot A}{c_{\mathrm{Na}^{+}, 0} \cdot Q \cdot F}
$$

where $j_{\mathrm{c}}$ is the applied current density $\left(\mathrm{A} \cdot \mathrm{m}^{-2}\right), A$ is the active membrane area $\left(0.01 \mathrm{~m}^{2}\right), c_{\mathrm{Na}^{+}, 0}$ is the molar concentration in the influent solution $\left(500 \mathrm{~mol} \cdot \mathrm{m}^{-3}\right), Q$ is the flow rate of the influent $\left(\mathrm{m}^{3} \cdot \mathrm{s}^{-1}\right)$, and $F$ is the Faraday constant (96485 C. $\left.\mathrm{mol}^{-1}\right)$. The $\mathrm{Na}^{+}$load ratio $\left(L_{\mathrm{Na}^{+}}\right)$is a dimensionless parameter that describes the ratio between the potential transport of $\mathrm{Na}^{+}$ at a given current density and the amount of $\mathrm{Na}^{+}$fed into the system. In principle, when $L_{\mathrm{Na}^{+}}=1$, the current in the cell is sufficient to transport all of the sodium toward the cathode. Thus, all of the (bi)carbonate ions react with protons leading to the maximum desorption of $\mathrm{CO}_{2}$ and regeneration of absorbent.

Besides, $L_{\mathrm{Na}^{+}}$can also be expressed as follows

$$
L_{\mathrm{Na}^{+}}=\frac{j_{\mathrm{c}} \cdot \tau}{c_{\mathrm{Na}^{+}, 0} \cdot F \cdot d}
$$

where $\tau$ is the residence time of the solution in the acidifying compartment ( $\mathrm{s}$ ) and $d$ is the thickness of the acidifying compartment $\left(5 \times 10^{-4} \mathrm{~m}\right) \cdot L_{\mathrm{Na}^{+}}$is proportional to $\tau$ when the current density applied is fixed. Therefore, within the scope of this work, a higher $L_{\mathrm{Na}}{ }^{+}$implies a longer residence time of the solution in the cell.

2.1.3. Experimental Procedure. All of the experiments were performed in continuous mode, according to the scheme in Figure 1. The composition of the influent was chosen to mimic a spent capture solution from a DAC process. Specifically, we considered a $0.5 \mathrm{M} \mathrm{NaOH}$ aqueous solution as absorbent, and we assumed that the capture step is completed when $\mathrm{CO}_{2}$ in the gas phase and in the liquid phase reaches equilibrium. As a result, the spent absorbent solution consists of $0.175 \mathrm{M}$ $\mathrm{Na}_{2} \mathrm{CO}_{3}$ and $0.150 \mathrm{M} \mathrm{NaHCO}_{3}$, based on Henry's law and the $\mathrm{CO}_{2}$ equilibria shown in eqs 2-4. The spent absorbent solution has a $\mathrm{pH}$ of 9.7 and a conductivity of $30.6 \mathrm{mS} \cdot \mathrm{cm}^{-1}$.

First, experiments at different $L_{\mathrm{Na}^{+}}$values were performed while keeping the current density constant. Then, the effect of current density was investigated at constant $L_{\mathrm{Na}}{ }^{+}$values. The experiments were performed until the system reached a steady state (i.e., by monitoring the outlet conductivity). Table S1 shows an overview of all of the experiments that were performed.

2.1.4. Figures of Merit. Here, we define the figures of merit associated with energy consumption and the regeneration of the alkaline absorbent. The specific energy consumption of the system $\left(\mathrm{EC}, \mathrm{J} \cdot \mathrm{mol}^{-1}\right)$ is defined as

$$
\mathrm{EC}=\frac{V_{\text {cell }} I+P_{\mathrm{H}_{2}}}{j_{\mathrm{CO}_{2}}}
$$

where $V_{\text {cell }}$ is the cell voltage $(\mathrm{V}), I$ is the applied current $(\mathrm{A})$, $P_{\mathrm{H}_{2}}$ is the power for production of $10 \%$ excess $\mathrm{H}_{2}$ in the electrolyzer $(\mathrm{W})$, and $j_{\mathrm{CO}_{2}}$ is the measured $\mathrm{CO}_{2}$ production rate $\left(\mathrm{mol} \cdot \mathrm{s}^{-1}\right) . P_{\mathrm{H}_{2}}$ is included in the calculations to compensate for possible small $\mathrm{H}_{2}$ gas leakage in practice. Note that we assumed the $\mathrm{H}_{2}$ production at the cathode fully compensates the $\mathrm{H}_{2}$ requirement at the anode in optimized cell designs (i.e., gas-tight).

The primary purpose of the system is to regenerate the alkaline absorbent. As the maximum total carbon concentration in the spent absorbent is determined by the $\mathrm{CO}_{2}$ partial pressure in the air, the regenerated $\mathrm{CO}_{2}$ capture capacity of the absorbent equals the amount of total carbon removed during the regeneration. The total carbon removed during the regeneration is in the form of desorption of $\mathrm{CO}_{2}(\mathrm{~g})$. Therefore, we define a "carbon removal efficiency" ( $\left.\xi_{\text {removal }}\right)$ to quantify the efficiency of the absorbent regeneration step, and it is expressed as 


$$
\xi_{\text {removal }}=1-\frac{c_{\mathrm{t}, 2}}{c_{\mathrm{t}, 0}}
$$

where $c_{\mathrm{t}, 2}$ and $c_{\mathrm{t}, 0}$ are the total carbon concentration in the cathode outlet and influent, respectively $\left(\mathrm{mol} \cdot \mathrm{m}^{-3}\right)$.

Finally, we describe the potential drop over the cell as a sum of equilibrium potential $\left(V_{\text {eq }}\right)$, anode overpotential $\left(\eta_{\text {anode }}\right)$, cathode overpotential $\left(\eta_{\text {cathode }}\right)$, ionic losses $\left(V_{\text {ionic }}\right)$, and transport losses $\left(V_{\text {transport }}\right)$. Further details on the calculations can be found in the Supporting Information.

2.2. Equilibrium Model. An equilibrium model was developed for the acidifying and cathode compartments, based on mass balance and transport equations of $\mathrm{Na}^{+}$and $\mathrm{H}^{+}$. The model considers steady-state conditions, well-mixed compartments, and ideal CEM behavior (i.e., a complete rejection of co-ions). The anode was excluded from this framework to simplify the system. Hence, we also assume that protons are produced in the acidifying compartment and consumed at the cathode (i.e., assuming hydrogen evolution from protons instead of from water). Furthermore, the recirculation of each compartment is not considered in the model, and the outlet from the acidifying compartment flows directly to the cathode.

Neglecting any net transport of water through the membrane, the mass balance for sodium in the acidifying compartment can be written as

$$
J_{\mathrm{Na}^{+}}=\frac{Q}{A} \cdot\left(c_{\mathrm{Na}^{+}, 0}-c_{\mathrm{Na}^{+}, 1}\right)
$$

where $J_{\mathrm{Na}^{+}}$is the molar flux of $\mathrm{Na}^{+}$through the CEM, and $c_{\mathrm{Na}^{+}, 0}$ and ${\mathcal{C N a}^{+}, 1}_{1}$ are the $\mathrm{Na}^{+}$concentrations at the inlet and outlet of the acidifying compartment, respectively.

The mass balance of total carbon species is related to the $\mathrm{CO}_{2}$ production in the acidifying compartment. The total carbon concentration in the anode outflow $\left(c_{\mathrm{t}, 1}\right)$ in equilibrium with the gas phase in the membrane contactor ( 1 atm pure $\left.\mathrm{CO}_{2}\right)$ is thus a function of sodium concentration $\left(c_{\mathrm{Na}^{+}, 1}\right)$ and $\mathrm{CO}_{2}$ partial pressure. If $c_{\mathrm{t}, 1}$ is lower than the total carbon concentration in the anode inflow $\left(c_{\mathrm{t}, 0}\right)$, the reduction of total carbon in the liquid phase is desorbed into the gas phase as $\mathrm{CO}_{2}$ gas. Therefore, the specific $\mathrm{CO}_{2}$ production rate $\left(\mathrm{J}_{\mathrm{CO}_{2}}\right)$ can be defined as

$$
J_{\mathrm{CO}_{2}}=\frac{Q}{A} \cdot\left(c_{\mathrm{t}, 0}-c_{\mathrm{t}, 1}\right)
$$

Note that $J_{\mathrm{CO}_{2}}$ is normalized for the active area of the cell. If $c_{\mathrm{t}, 1}$ is calculated to be higher than $c_{\mathrm{t}, 0}$, we consider the acidifying compartment as a closed system, which has no gas production and $c_{\mathrm{t}, 1}=c_{\mathrm{t}, 0}$.

In the cathode compartment, since ideally no carbon species can pass through the membrane, the total concentration of carbon species remains constant, i.e., $c_{\mathrm{t}, 2}=c_{\mathrm{t}, 1}$ and $c_{\mathrm{Na}^{+}, 2}=c_{\mathrm{Na}^{+}, 0}$, where the subscript " 2 " indicates the cathode outlet.

The total ionic current through the CEM is given by

$$
j_{\mathrm{c}}=J_{\mathrm{Na}^{+}}+J_{\mathrm{H}^{+}}
$$

where $J_{\mathrm{H}^{+}}$is the molar flux of $\mathrm{H}^{+}$through the membrane. Both cation fluxes can be calculated by considering the NernstPlanck equation. The electroneutrality condition inside the CEM gives

$$
c_{\mathrm{Na}^{+}}+c_{\mathrm{H}^{+}}=c_{\mathrm{X}}
$$

where $c_{\mathrm{X}}$ is the fixed charge density of the cation exchange membrane. Therefore, the Nernst-Planck equation for $J_{\mathrm{Na}^{+}}$ and $\mathrm{J}_{\mathrm{H}^{+}}$can be rewritten as

$$
\begin{aligned}
& J_{\mathrm{Na}^{+}}=-D \cdot c_{\mathrm{X}} \cdot\left(\frac{\mathrm{d} f_{\mathrm{Na}^{+}}}{\mathrm{d} x}+f_{\mathrm{Na}^{+}} \frac{\mathrm{d} \phi}{\mathrm{d} x}\right) \\
& J_{\mathrm{H}^{+}}=-a \cdot D \cdot c_{\mathrm{X}} \cdot\left(\frac{\mathrm{d} f_{\mathrm{H}^{+}}}{\mathrm{d} x}+f_{\mathrm{H}^{+}} \frac{\mathrm{d} \phi}{\mathrm{d} x}\right)
\end{aligned}
$$

where $D$ is the diffusion coefficient of $\mathrm{Na}^{+}$inside the membrane, $a$ is the ratio between the diffusion coefficient of $\mathrm{H}^{+}$and $\mathrm{Na}^{+}, \phi$ the electric potential, $x$ the position inside the membrane, and $f_{\mathrm{Na}^{+}}$and $f_{\mathrm{H}^{+}}$are the concentration fractions of $\mathrm{Na}^{+}$and $\mathrm{H}^{+}$, respectively $\left(f_{\mathrm{Na}^{+}}=c_{\mathrm{Na}^{+}} / c_{\mathrm{X}}, f_{\mathrm{H}^{+}}=c_{\mathrm{H}^{+}} / c_{\mathrm{X}}\right)$.

The ion concentration in the bulk solution is the same as the ion concentration on the membrane surface since we assumed perfectly stirred compartments (i.e., no concentration polarization phenomena). By combining eqs 7 and 8 into eq 5 a, the total ionic current is equal to

$$
\begin{aligned}
j_{\mathrm{c}}= & -D \cdot \frac{c_{\mathrm{X}}}{\delta} \cdot\left\{(a-1) \cdot\left(f_{\mathrm{H}^{+}, \mathrm{c}}-f_{\mathrm{H}^{+}, \mathrm{a}}\right)\right. \\
& \left.+\left[1+(a-1) \cdot \frac{f_{\mathrm{H}^{+}, \mathrm{c}}+f_{\mathrm{H}^{+}, \mathrm{a}}}{2}\right] \cdot \mathrm{d} \phi\right\}
\end{aligned}
$$

where $\delta$ is the CEM thickness and the subscripts a and c indicate the acidifying and cathode sides of the membrane, respectively. Furthermore, the transport number of $\mathrm{Na}^{+}\left(t_{\mathrm{Na}^{+}}\right)$ is defined as

$$
t_{\mathrm{Na}^{+}}=\frac{J_{\mathrm{Na}^{+}}}{j_{\mathrm{c}}}
$$
by

Finally, the specific energy consumption $\left(\mathrm{EC}^{0}\right)$ is calculated

$$
\mathrm{EC}^{0}=\frac{V_{\text {total }}{ }^{\circ} j_{\mathrm{c}}}{J_{\mathrm{CO}_{2}}}
$$

where $V_{\text {total }}$ is the total cell voltage, which is calculated as the sum of ohmic losses $\left(V_{\text {ohmic }}\right)$, potential drop due to the $\mathrm{pH}$ difference in the cell $\left(V_{\mathrm{pH}}\right)$, and membrane potential $\left(V_{\text {membrane }}\right)$.

$$
V_{\text {total }}=V_{\text {ohmic }}+V_{\mathrm{pH}}+V_{\text {membrane }}
$$

$V_{\text {ohmic }}$ is the potential loss related to the ohmic resistance of the acidifying and cathode compartments and can be expressed as

$$
V_{\text {ohmic }}=j_{\mathrm{c}} \cdot\left(\frac{d_{\mathrm{a}}}{\sigma_{\mathrm{a}}}+\frac{d_{\mathrm{c}}}{\sigma_{\mathrm{c}}}\right)
$$

where $d_{\mathrm{a}}$ and $d_{\mathrm{c}}$ are the thicknesses of acidifying and cathode compartments, respectively, $\sigma_{\mathrm{a}}$ and $\sigma_{\mathrm{c}}$ are the conductivities of acidifying solution and catholyte (calculated by OLIStudio version 9.5 (OLI Systems, Inc., NJ) based on the solution composition), respectively.

$V_{\mathrm{pH}}$ is determined by the $\mathrm{pH}$ difference between anode and cathode considering a potential drop of $59.2 \mathrm{mV}$ per $\mathrm{pH}$ unit, and $\mathrm{pH}_{\text {anode }}=1$ due to the high proton concentration in the MEA 

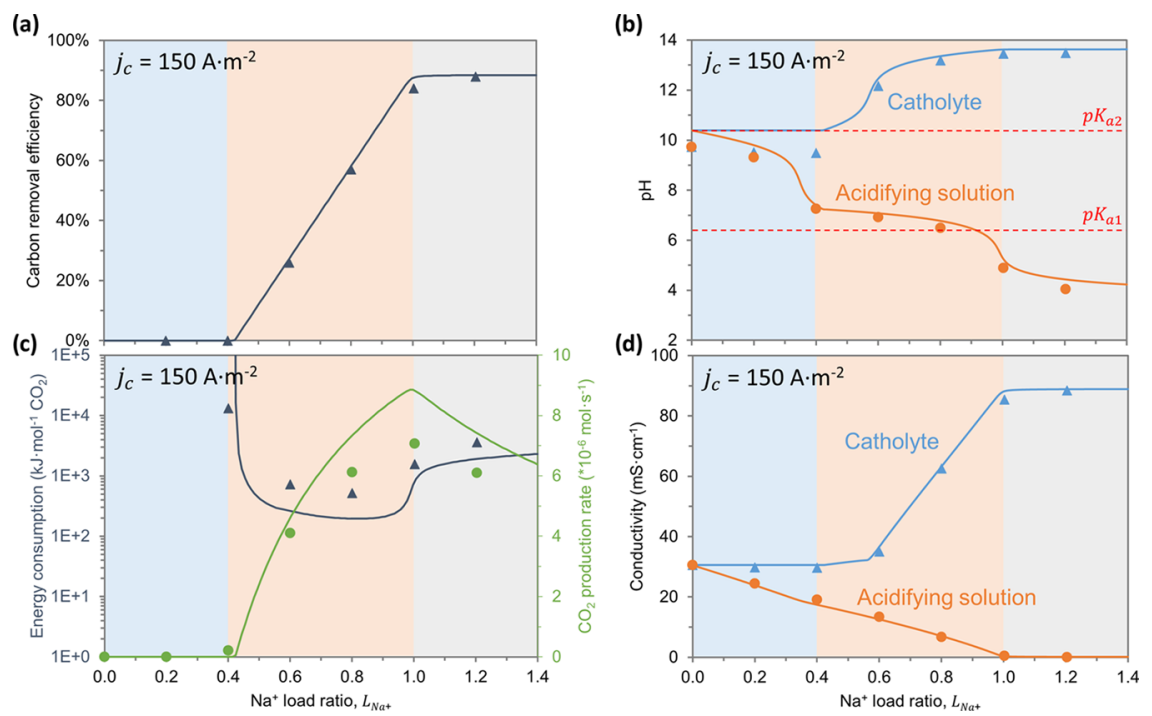

Figure 2. Effect of $\mathrm{Na}^{+}$load ratio on the cell performance at a constant current density $\left(150 \mathrm{~A} \cdot \mathrm{m}^{-2}\right)$. (a) Carbon removal efficiency, (b) pH, (c) specific energy consumption and $\mathrm{CO}_{2}$ production rate, and (d) electrical conductivity. Symbols $(\mathbf{A})$ : experimental data; lines: model results.

$$
V_{\mathrm{pH}}=0.0592 \cdot\left(\mathrm{pH}_{\text {cathode }}-1\right)
$$

$V_{\text {membrane }}$ is the Donnan potential across the CEM and is determined by the sodium concentration on each side of the membrane

$$
V_{\text {membrane }}=\frac{R \cdot T}{F} \cdot \ln \frac{c_{\mathrm{Na}^{+}, 2}}{c_{\mathrm{Na}^{+}, 1}}
$$

The model requires as input the properties of the influent (i.e., $c_{\mathrm{Na}^{+}, 0}, c_{\mathrm{t}, 0}$, and $Q$ ) and the $\mathrm{Na}^{+}$concentration of the outlet acidifying solution $\left(\mathrm{C}_{\mathrm{Na}^{+}, 1}\right)$, and then calculates the current density, $\mathrm{Na}^{+}$load ratio, $\mathrm{CO}_{2}$ production rate, and outlet concentration as output.

\section{RESULTS AND DISCUSSION}

3.1. Effect of $\mathrm{Na}^{+}$Load Ratio. We first tested the cell under constant current operations and investigated the effect of the $\mathrm{Na}^{+}$load ratio $\left(L_{\mathrm{Na}^{+}}\right)$by varying the influent flow rate. Figure 2 shows both the experimental and theoretical results obtained with $L_{\mathrm{Na}}{ }^{+}$ranging from 0.2 to 1.2 at a constant current density $\left(150 \mathrm{~A} \cdot \mathrm{m}^{-2}\right)$.

The carbon removal efficiency as a function of load ratio clearly shows three different regimes (Figure 2a): (i) $L_{\mathrm{Na}^{+}}<$ 0.4; (ii) $L_{\mathrm{Na}^{+}}=0.4-1$, and (iii) $L_{\mathrm{Na}^{+}}>1$. For $L_{\mathrm{Na}^{+}}<0.4$, no carbon removal is observed. Based on the $\mathrm{CO}_{2}$ equilibria shown in eqs 2-4, we calculated that $\mathrm{CO}_{2}$ can only be desorbed into the gas phase when the $\mathrm{pH}$ is lower than 7.3 (i.e., assuming that the acidifying solution is in equilibrium with $1 \mathrm{~atm}$ pure $\mathrm{CO}_{2}$ in the gas phase of the membrane contactor). In fact, in this regime at $L_{\mathrm{Na}^{+}}<0.4$, the $\mathrm{pH}$ of the acidifying solution is higher than 7.3 (Figure 2b). Consequently, the $\mathrm{CO}_{2}$ production rate is zero (Figure $2 \mathrm{c}$ ). The invested energy is, however, essential for achieving the suitable $\mathrm{pH}$ conditions to desorb $\mathrm{CO}_{2}$ at higher $\mathrm{L}_{\mathrm{Na}^{+}}$. The reason is that the $\mathrm{H}^{+}$produced in this first regime is used to convert $\mathrm{CO}_{3}{ }^{2-}$ to $\mathrm{HCO}_{3}{ }^{-}$and a small amount of $\mathrm{H}_{2} \mathrm{CO}_{3}{ }^{*}$ so that further accumulation of $\mathrm{H}_{2} \mathrm{CO}_{3} *$ can lead to $\mathrm{CO}_{2}$ desorption. Finally, Figure $2 \mathrm{~d}$ shows a linear decrease of the electrical conductivity of the acidifying solution, since $\mathrm{Na}^{+}$is transported to the cathode and $\mathrm{CO}_{3}{ }^{2-} / \mathrm{HCO}_{3}{ }^{-}$are neutralized by $\mathrm{H}^{+}$. Meanwhile, the electrical conductivity of catholyte is constant correspond- ing to the constant $\mathrm{pH}$ shown in Figure $2 \mathrm{~b}$ because the solution reverts to the composition of the influent of the cell (i.e., the change caused by $\mathrm{H}^{+}$produced at the anode is neutralized by the $\mathrm{OH}^{-}$produced at the cathode).

In the second regime at $L_{\mathrm{Na}^{+}}$between 0.4 and 1.0, the carbon removal efficiency and $\mathrm{CO}_{2}$ production rate increase with $L_{\mathrm{Na}^{+}}$ due to the lower $\mathrm{pH}$ in the acidifying compartment, showing that the carbon species in the spent solution are removed as desorbed $\mathrm{CO}_{2}$. Besides, the conductivity of the acidifying solution keeps decreasing as a higher amount of $\mathrm{Na}^{+}$is transported to the cathode and $\mathrm{CO}_{3}{ }^{2-} / \mathrm{HCO}_{3}{ }^{-}$are neutralized by $\mathrm{H}^{+}$. Due to the decrease of ionic conductivity of the acidifying solution, the ohmic resistance of the cell increases with the load ratio. As a result of the trade-off between the increasing $\mathrm{CO}_{2}$ production rate and the increasing ohmic resistance, we experimentally reached a minimum specific energy consumption of $520 \mathrm{~kJ} \cdot \mathrm{mol}^{-1} \mathrm{CO}_{2}$ at $L_{\mathrm{Na}^{+}}=0.8$ and $j_{\mathrm{c}}=$ $150 \mathrm{~A} \cdot \mathrm{m}^{-2}$.

In the third regime at $L_{\mathrm{Na}^{+}}>1.0$, the carbon removal efficiency reaches a plateau, and the $\mathrm{CO}_{2}$ production rate starts to decrease after it reaches a maximum at $L_{\mathrm{Na}^{+}}=1.0$. By definition, $L_{\mathrm{Na}^{+}}>1.0$ implies that the applied current is sufficient to transport all of the $\mathrm{Na}^{+}$from the acidifying compartment to the cathode compartment. As a result, the $\mathrm{pH}$ of the acidifying solution is so low that most of the carbon species in the aqueous solution are in the form of $\mathrm{H}_{2} \mathrm{CO}_{3}{ }^{*}$. Therefore, the carbon removal efficiency is mostly limited by the $\mathrm{CO}_{2}$ partial pressure in the gas phase of the membrane contactor, which is constant at 1 atm. Moreover, the $\mathrm{CO}_{2}$ production is limited by the amount of total carbon feeding into the system and not by the $\mathrm{pH}$ of the acidifying solution. The $\mathrm{CO}_{2}$ production rate decreases at $L_{\mathrm{Na}^{+}}>1.0$, since less influent and hence less total carbon is supplied than those at $L_{\mathrm{Na}^{+}}<1$ 1.0. Furthermore, the transport number of $\mathrm{Na}^{+}$ decreases at $\mathrm{L}_{\mathrm{Na}^{+}}>1.0$ (Figure $\mathrm{S} 1$ ), and some $\mathrm{H}^{+}$ions in the acidifying solution are transported through the CEM rather than contributing to the $\mathrm{CO}_{2}$ desorption, as shown by the decreasing $\mathrm{CO}_{2}$ production rate in the last regime. Finally, the conductivity in the acidifying compartment is as low as 0.43 $\mathrm{mS} \cdot \mathrm{cm}^{-1}\left(L_{\mathrm{Na}^{+}}=1.0\right)$ and $0.08 \mathrm{mS} \cdot \mathrm{cm}^{-1}\left(L_{\mathrm{Na}^{+}}=1.2\right)$. As a 

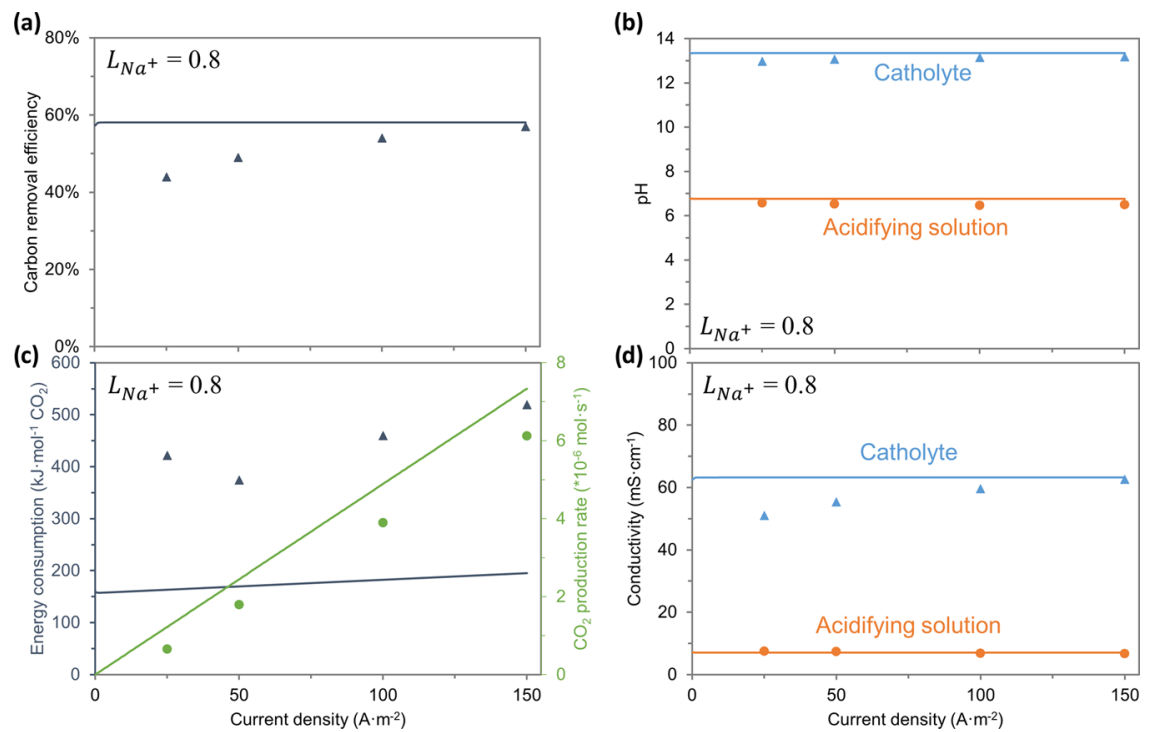

Figure 3. Effect of current density and flow rate at a constant $\mathrm{Na}^{+}$load ratio. (a) $\mathrm{pH}$, (b) $\mathrm{CO}_{2}$ production rate, (c) specific energy consumption and $\mathrm{CO}_{2}$ production rate, and (d) electrical conductivity. Symbols $(\mathbf{O})$ : experimental data; lines: model results.

result, the ohmic resistance in the compartment significantly increases in this regime, leading to high energy consumption.

The carbon removal efficiency shown in Figure 2a also indicates the regeneration efficiency of the $\mathrm{CO}_{2}$ capture capacity of the absorbent. At $L_{\mathrm{Na}^{+}}=0.8, \xi_{\text {removal }}=57 \%$ implies that $57 \%$ of the $\mathrm{CO}_{2}$ capture capacity of the absorbent is regenerated. The outlet catholyte reaches a $\mathrm{pH}$ of 13.19 and a conductivity of $62.58 \mathrm{mS} \cdot \mathrm{cm}^{-1}$, which leads to a final composition of $0.22 \mathrm{M} \mathrm{NaOH}$ and $0.14 \mathrm{M} \mathrm{Na}_{2} \mathrm{CO}_{3}$ (calculated by OLIStudio based on measured conductivity). Given this $\mathrm{OH}^{-} / \mathrm{CO}_{3}{ }^{2-}$ molar ratio, we believe that such a solution can be directly reused as an absorbent for DAC. In comparison, Keith et al. used an aqueous solution of $1.0 \mathrm{M} \mathrm{KOH}$ and $0.5 \mathrm{M}$ $\mathrm{K}_{2} \mathrm{CO}_{3}$ as an absorbent in their DAC pilot plant that has a very close $\mathrm{OH}^{-} / \mathrm{CO}_{3}{ }^{2-}$ molar ratio to our regenerated absorbent. ${ }^{16}$

Furthermore, Figure 2 also shows a good agreement between the model simulations and experimental data. In particular, the model predicts the same trend for carbon removal efficiency, $\mathrm{pH}$, and conductivity (Figure 2a,b,d), thus proving the validity of the mass balance calculations in the system. Regarding the $\mathrm{CO}_{2}$ production rate (Figure $2 \mathrm{c}$ ), the model overestimates by $12-20 \%$ the experimental results, likely due to some $\mathrm{CO}_{2}$ leakage occurring in the experimental setup. The residence time of the solution in the system increases at a higher load ratio due to the lower influent flow rate, so the risk of gas leakage also increases. Despite the overestimation by the model, the simulation results correctly predict a maximum for $\mathrm{CO}_{2}$ production rate at $L_{\mathrm{Na}^{+}}=1.0$, where the limiting factor for $\mathrm{CO}_{2}$ desorption shifts from the solution $\mathrm{pH}$ to the amount of carbon available in the bulk solution.

Regarding the energy consumption, the model correctly predicts the experimental trend, but it gives lower values compared to experimental data (Figure 2c). Such difference can be due to some of the simplifying assumptions, i.e., the absence of gas leakage $\left(\mathrm{CO}_{2}\right.$ and $\left.\mathrm{H}_{2}\right)$ and of electrode overpotentials. In particular, the model predicts a minimum energy consumption of $195 \mathrm{~kJ} \cdot \mathrm{mol}^{-1} \mathrm{CO}_{2}$ and a carbon removal efficiency of $59 \%$ at $L_{\mathrm{Na}^{+}}{ }^{+}=0.8$. We believe that these values predicted by the model can be experimentally achieved by further optimization of the system (i.e., minimizing the gas leakage and electrode overpotentials).

3.2. Effect of Current Density at a Constant Load Ratio. The tests at different $\mathrm{Na}^{+}$load ratios showed that the lowest energy consumption for the system is achieved at $L_{\mathrm{Na}^{+}}=$ 0.8 . To further study the effect of current density on the energy consumption, we performed experiments with current density ranging from 25 to $150 \mathrm{~A} \cdot \mathrm{m}^{-2}$ at a fixed load ratio. During the tests, the influent flow rate was modified in line with the current density to maintain a constant $L_{\mathrm{Na}^{+}}$of 0.8 . Experimental and theoretical results are shown in Figure 3.

As the model has been validated in the previous section for prediction of carbon removal efficiency, $\mathrm{pH}$, and conductivity, we believe the simulations also predict the behavior of these parameters at different current densities correctly. Figure 3a shows that the carbon removal efficiency remains constant with the change of current density due to an identical steady state obtained at the same value of $L_{\mathrm{Na}^{+}}$. This identical steady state is also demonstrated by the constant $\mathrm{pH}$ and conductivity (Figure $3 \mathrm{~b}, \mathrm{~d}$ ). The $\mathrm{CO}_{2}$ production rate increases linearly with the current density due to the higher flux of $\mathrm{H}^{+}$from the anode and higher total carbon loading, as a result of the increasing influent flow rate (Figure 3c).

Nevertheless, we also noted differences between the simulation and experimental results. In particular, the difference in carbon removal efficiency, conductivity of catholyte, and $\mathrm{CO}_{2}$ production rate can be explained by the leakage of carbon species from the system and inside the system. The tests at lower current density have a lower influent flow rate, which leads to longer residence time and larger gas leakage. Furthermore, the neutral carbon species $\left(\mathrm{H}_{2} \mathrm{CO}_{3} *\right)$, instead of being desorbed as $\mathrm{CO}_{2}(\mathrm{~g})$, can be transported from the acidifying compartment to the cathode compartment under a concentration gradient. ${ }^{34}$ Once in the cathode compartment, the $\mathrm{H}_{2} \mathrm{CO}_{3}$ * can react with $\mathrm{OH}^{-}$in the catholyte to produce $\mathrm{CO}_{3}{ }^{2-}$, thus decreasing the ionic conductivity (since $\mathrm{CO}_{3}{ }^{2-}$ has a lower ion conductivity than $\mathrm{OH}^{-}$). Therefore, the longer residence time at low-current-density tests increases the leakage of carbon species. 
Such leakage is also visible in the increased energy consumption in the test at $j_{\mathrm{c}}=25 \mathrm{~A} \cdot \mathrm{m}^{-2}$ (Figure 3c). With lower current density, we expected lower energy consumption due to minor energy losses from the internal resistance and overpotential, which is in agreement with the tests at 50-150 $\mathrm{A} \cdot \mathrm{m}^{-2}$. However, we observed a higher energy consumption at $j_{\mathrm{c}}=25 \mathrm{~A} \cdot \mathrm{m}^{-2}$ compared to the test at $j_{\mathrm{c}}=50 \mathrm{~A} \cdot \mathrm{m}^{-2}$. As shown by the similar difference between simulation and experimental results of the $\mathrm{CO}_{2}$ production rate, the leakage of $\mathrm{CO}_{2}$ is at a constant rate. Thus, the leakage has a greater impact on the energy consumption at a lower current density since the fraction of $\mathrm{CO}_{2}$ leaked from the system is larger. The modeling results identify the importance of minimizing the leakage and thus directly point to the need of improving the gas-tightness of the setup in future studies.

We achieved the lowest energy consumption of $374 \mathrm{~kJ} \cdot \mathrm{mol}^{-1}$ $\mathrm{CO}_{2}$ at a current density of $50 \mathrm{~A} \cdot \mathrm{m}^{-2}$. In that case, the outlet solution from the cathode compartment reached $\mathrm{pH} 13.07$ and the final composition of $0.167 \mathrm{M} \mathrm{NaOH}$ and $0.1665 \mathrm{M}$ $\mathrm{Na}_{2} \mathrm{CO}_{3}$, corresponding to a $49 \%$ carbon removal efficiency. In addition, the gas desorbed from the membrane contactor contains more than $95 \%$ of $\mathrm{CO}_{2}$ in the test at $j_{\mathrm{c}}=50 \mathrm{~A} \cdot \mathrm{m}^{-2}$. This high-purity $\mathrm{CO}_{2}$ gas is suitable for subsequent storage or utilization. ${ }^{35}$ Without the leakage of $\mathrm{CO}_{2}$, as predicted by the model, the specific energy consumption increases gradually with the current density (Figure $3 \mathrm{c}$ ). At $j_{\mathrm{c}}=25 \mathrm{~A} \cdot \mathrm{m}^{-2}$, a specific energy consumption of $164 \mathrm{~kJ} \cdot \mathrm{mol}^{-1} \mathrm{CO}_{2}$ is predicted, which represents the lowest value of energy consumption for our system in the investigated operational range. Such an operating condition results in a 58\% carbon removal efficiency and with a final solution composition suitable for use as a DAC absorbent.

The energy consumption experimentally measured is higher than the theoretical values (Figure $3 \mathrm{~d}$ ). To investigate this difference, we analyzed the potential losses in the cell at different current densities. Figure 4 shows the contribution of

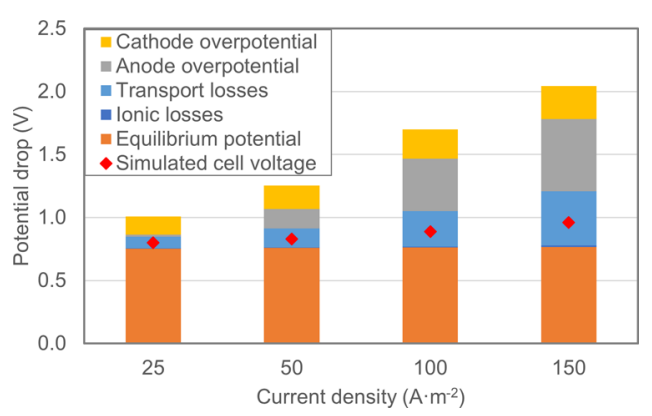

Figure 4. Relative contributions of potential drops in the system at different current densities and constant $\mathrm{Na}^{+}$load ratio $\left(L_{\mathrm{Na}^{+}}{ }^{+}=0.8\right)$. Symbol $(\downarrow)$ represents the cell voltage predicted by the model.

the potential drops to the cell voltage during the tests shown in Figure 3. At a low current density, the cell voltage is clearly dominated by the equilibrium potential $\left(V_{\text {eq }}\right)\left(75 \%\right.$ of $V_{\text {cell }}$ at $\left.25 \mathrm{~A} \cdot \mathrm{m}^{-2}\right)$, while its contribution to the cell voltage decreases at a higher current density $\left(38 \%\right.$ of $V_{\text {cell }}$ at $\left.150 \mathrm{~A} \cdot \mathrm{m}^{-2}\right)$. The value of $V_{\text {eq }}$ is independent of the applied current density due to the constant $\mathrm{pH}$ difference between anode and cathode (at constant $\mathrm{Na}^{+}$load ratio). However, all other potential losses increase by increasing the current density. The overpotential of the anode $\left(\eta_{\text {anode }}\right)$ and the cathode $\left(\eta_{\text {cathode }}\right)$ reach their highest contribution at $j_{\mathrm{c}}=150 \mathrm{~A} \cdot \mathrm{m}^{-2}, 28$ and $13 \%$ of the cell voltage, respectively. The Donnan potential given by the CEM of the MEA was included as part of the anode overpotential; thus, the current density has a larger effect on $\eta_{\text {anode }}$. Moreover, the transport losses $\left(V_{\text {transport }}\right)$ increase with current density until reaching $20 \%$ of the cell voltage at $150 \mathrm{~A} \cdot \mathrm{m}^{-2}$. In this context, $V_{\text {transport }}$ refers to the remaining losses in the system, such as the losses caused by the formation of gas bubbles both in the acidifying compartment $\left(\mathrm{CO}_{2}\right)$ and in the cathode $\left(\mathrm{H}_{2}\right)$. Finally, the ionic losses due to the ohmic resistance of the solution ( $\left.V_{\text {ionic }}\right)$ are negligible, due to the high ionic conductivity at $L_{\mathrm{Na}^{+}}=0.8$.

The model captures the equilibrium potential, ionic losses, and membrane potential (as a part of the transport losses). This part of potential losses remains stable with the increase of current density, while the remaining losses increase dramatically. Therefore, although the model predicted $80 \%$ of the total potential drop at $25 \mathrm{~A} \cdot \mathrm{m}^{-2}$, only $48 \%$ is predicted when the current density rises to $150 \mathrm{~A} \cdot \mathrm{m}^{-2}$. The difference is mainly due to the overpotential of the electrodes and other nonideal losses, which could be contributed by reaction kinetics, boundary layers, and bubble formation. ${ }^{22,25}$ The deviation between the modeling results and experimental data indicates that further refinement of the model and measurements is needed to identify the contribution of each of these processes and propose improved designs. On a cell design level, future research efforts should be focused on reducing gas leakage. Moreover, different electrode materials could be tested to reduce the electrode overpotential, for instance, using different membrane electrode assemblies or highly electroactive materials for hydrogen evolution. Finally, further studies should be focused on optimizing the electrolyte compositions, aiming to decrease the transport losses in the system and provide more insights into the reaction kinetics.

The proposed $\mathrm{H}_{2}$-recycling electrochemical system shows the ability to regenerate the spent alkaline absorbent from DAC and produce a high-purity $\mathrm{CO}_{2}$ gas stream. We experimentally achieved a minimum energy consumption of $374 \mathrm{~kJ} \cdot \mathrm{mol}^{-1} \mathrm{CO}_{2}$, while the model simulation has shown energy consumption of the system as low as $164 \mathrm{~kJ} \cdot \mathrm{mol}^{-1} \mathrm{CO}_{2}$ by further optimization. Such low-energy-consumption values are in line with other regeneration strategies proposed for $\mathrm{DAC}$, thus showing that this electrochemical process can be a competitive alternative among all DAC technologies. For instance, Keith et al. showed an energy consumption of $338 \mathrm{~kJ}$. $\mathrm{mol}^{-1} \mathrm{CO}_{2}$ for their thermodynamic cycle, ${ }^{16}$ while Sabatino et al. estimated an energy consumption of $236 \mathrm{~kJ} \cdot \mathrm{mol}^{-1} \mathrm{CO}_{2}$ for bipolar membrane electrodialysis. ${ }^{28}$ Besides, up to $59 \%$ of the $\mathrm{CO}_{2}$ capture capacity of the absorbent could be regenerated during the process, which made the effluent from the system suitable for DAC systems. Furthermore, another advantage of such an electrochemical system for $\mathrm{CO}_{2}$ desorption is that it does not require any heat for the absorbent regeneration (unlike most of the proposed DAC technologies ${ }^{16,36}$ ). Instead, it requires only electricity as energy input, so it can be easily coupled to renewable energy sources for a sustainable DAC process. Finally, the desorption of $\mathrm{CO}_{2}$ and regeneration of alkaline absorbent occurring in one step represents a clear advantage for the reduction of the overall operational costs, since it simplifies the process operation compared to energyintensive processes such as causticization. ${ }^{18}$ 


\section{ASSOCIATED CONTENT}

\section{(1) Supporting Information}

The Supporting Information is available free of charge at https://pubs.acs.org/doi/10.1021/acs.est.0c01977.

List of the performed experiments; calculations of potential drops; definition and results of transport number of $\mathrm{Na}^{+}$and some additional indicators (Figure S1 and Tables S1 and S2) (PDF)

\section{AUTHOR INFORMATION}

\section{Corresponding Author}

Philipp Kuntke - Wetsus, European Centre of Excellence for Sustainable Water Technology, 8911 MA Leeuwarden, The Netherlands; Department of Environmental Technology, Wageningen University, 6700 AA Wageningen, The Netherlands; ○ orcid.org/0000-0002-2342-8662; Phone: +31-58-2843000; Email: Philipp.Kuntke@wur.nl

\section{Authors}

Qingdian Shu - Wetsus, European Centre of Excellence for Sustainable Water Technology, 8911 MA Leeuwarden, The Netherlands; Department of Environmental Technology, Wageningen University, 6700 AA Wageningen, The Netherlands

Louis Legrand - Wetsus, European Centre of Excellence for Sustainable Water Technology, 8911 MA Leeuwarden, The Netherlands; Department of Environmental Technology, Wageningen University, 6700 AA Wageningen, The Netherlands

Michele Tedesco - Wetsus, European Centre of Excellence for Sustainable Water Technology, 8911 MA Leeuwarden, The Netherlands

Hubertus V. M. Hamelers - Wetsus, European Centre of Excellence for Sustainable Water Technology, 8911 MA Leeuwarden, The Netherlands; 이이. orcid.org/0000-0002-09904773

Complete contact information is available at: https://pubs.acs.org/10.1021/acs.est.0c01977

\section{Notes}

The authors declare no competing financial interest.

\section{ACKNOWLEDGMENTS}

This work was performed in the cooperation framework of Wetsus, European Centre of Excellence for Sustainable Water Technology (www.wetsus.eu). Wetsus is co-funded by the Dutch Ministry of Economic Affairs and Ministry of Infrastructure and Environment, the European Union Regional Development Fund, the Province of Fryslân, and the Northern Netherlands Provinces. The authors thank Francisco Miguel Azevedo Lima for performing the experiments and the participants of the research theme "Sustainable Carbon Cycle" for fruitful discussions and financial support.

\section{REFERENCES}

(1) Friedlingstein, P.; Houghton, R.; Marland, G.; Hackler, J.; Boden, T. A.; Conway, T.; Canadell, J.; Raupach, M.; Ciais, P.; Le Quere, C. Update on $\mathrm{CO}_{2}$ emissions. Nat. Geosci. 2010, 3, 811.

(2) Shakun, J. D.; Clark, P. U.; He, F.; Marcott, S. A.; Mix, A. C.; Liu, Z.; Otto-Bliesner, B.; Schmittner, A.; Bard, E. Global warming preceded by increasing carbon dioxide concentrations during the last deglaciation. Nature 2012, 484, 49-54.

(3) Cox, P. M.; Betts, R. A.; Jones, C. D.; Spall, S. A.; Totterdell, I. J. Acceleration of global warming due to carbon-cycle feedbacks in a coupled climate model. Nature 2000, 408, 184-187.
(4) Lashof, D. A.; Ahuja, D. R. Relative contributions of greenhouse gas emissions to global warming. Nature 1990, 344, 529-531.

(5) Le Quéré, C.; Andrew, R. M.; Canadell, J. G.; Sitch, S.; Korsbakken, J. I.; Peters, G. P.; Manning, A. C.; Boden, T. A.; Tans, P. P.; Houghton, R. A.; Keeling, R. F.; Alin, S.; Andrews, O. D.; Anthoni, P.; Barbero, L.; Bopp, L.; Chevallier, F.; Chini, L. P.; Ciais, P.; Currie, K.; Delire, C.; Doney, S. C.; Friedlingstein, P.; Gkritzalis, T.; Harris, I.; Hauck, J.; Haverd, V.; Hoppema, M.; Klein Goldewijk, K.; Jain, A. K.; Kato, E.; Körtzinger, A.; Landschützer, P.; Lefèvre, N.; Lenton, A.; Lienert, S.; Lombardozzi, D.; Melton, J. R.; Metzl, N.; Millero, F.; Monteiro, P. M. S.; Munro, D. R.; Nabel, J. E. M. S.; Nakaoka, S. I.; O’Brien, K.; Olsen, A.; Omar, A. M.; Ono, T.; Pierrot, D.; Poulter, B.; Rödenbeck, C.; Salisbury, J.; Schuster, U.; Schwinger, J.; Séférian, R.; Skjelvan, I.; Stocker, B. D.; Sutton, A. J.; Takahashi, T.; Tian, H.; Tilbrook, B.; van der Laan-Luijkx, I. T.; van der Werf, G. R.; Viovy, N.; Walker, A. P.; Wiltshire, A. J.; Zaehle, S. Global Carbon Budget 2016. Earth Syst. Sci. Data 2016, 8, 605-649.

(6) Stocker, T. Climate Change 2013: The Physical Science Basis: Working Group I Contribution to the Fifth Assessment Report of the Intergovernmental Panel on Climate Change; Cambridge University Press, 2014

(7) Gattuso, J.-P.; Hansson, L. Ocean Acidification; Oxford University Press, 2011.

(8) Orr, J. C.; Fabry, V. J.; Aumont, O.; Bopp, L.; Doney, S. C.; Feely, R. A.; Gnanadesikan, A.; Gruber, N.; Ishida, A.; Joos, F.; Key, R. M.; Lindsay, K.; Maier-Reimer, E.; Matear, R.; Monfray, P.; Mouchet, A.; Najjar, R. G.; Plattner, G.-K.; Rodgers, K. B.; Sabine, C. L.; Sarmiento, J. L.; Schlitzer, R.; Slater, R. D.; Totterdell, I. J.; Weirig, M.-F.; Yamanaka, Y.; Yool, A. Anthropogenic ocean acidification over the twenty-first century and its impact on calcifying organisms. Nature 2005, 437, 681-686.

(9) Caldeira, K.; Wickett, M. E. Oceanography: Anthropogenic carbon and ocean pH. Nature 2003, 425, 365.

(10) Edenhofer, O. Climate Change 2014: Mitigation of Climate Change; Cambridge University Press, 2015; Vol. 3.

(11) Keith, D. W. Why Capture $\mathrm{CO}_{2}$ from the Atmosphere? Science 2009, 325, 1654-1655.

(12) Lackner, K. S. Capture of carbon dioxide from ambient air. Eur. Phys. J.: Spec. Top. 2009, 176, 93-106.

(13) Lackner, K. S. The thermodynamics of direct air capture of carbon dioxide. Energy 2013, 50, 38-46.

(14) Sanz-Pérez, E. S.; Murdock, C. R.; Didas, S. A.; Jones, C. W. Direct Capture of $\mathrm{CO}_{2}$ from Ambient Air. Chem. Rev. 2016, 116, 11840-11876.

(15) Brethomé, F. M.; Williams, N. J.; Seipp, C. A.; Kidder, M. K.; Custelcean, R. Direct air capture of $\mathrm{CO}_{2}$ via aqueous-phase absorption and crystalline-phase release using concentrated solar power. Nat. Energy 2018, 3, 553-559.

(16) Keith, D. W.; Holmes, G.; St. Angelo, D.; Heidel, K. A Process for Capturing $\mathrm{CO}_{2}$ from the Atmosphere. Joule 2018, 2, 1573-1594.

(17) Stolaroff, J. K.; Keith, D. W.; Lowry, G. V. Carbon Dioxide Capture from Atmospheric Air Using Sodium Hydroxide Spray. Environ. Sci. Technol. 2008, 42, 2728-2735.

(18) Mahmoudkhani, M.; Keith, D. W. Low-energy sodium hydroxide recovery for $\mathrm{CO}_{2}$ capture from atmospheric airThermodynamic analysis. Int. J. Greenhouse Gas Control 2009, 3, 376-384.

(19) Lide, D. R. CRC Handbook of Chemistry and Physics; CRC Press, 2004; Vol. 85.

(20) Kim, S.; Choi, M.; Kang, J. S.; Joo, H.; Park, B. H.; Sung, Y.-E.; Yoon, J. Electrochemical recovery of $\mathrm{LiOH}$ from used $\mathrm{CO}_{2}$ adsorbents. Catal. Today 2019, DOI: 10.1016/j.cattod.2019.06.056.

(21) Rheinhardt, J. H.; Singh, P.; Tarakeshwar, P.; Buttry, D. A. Electrochemical Capture and Release of Carbon Dioxide. ACS Energy Lett. 2017, 2, 454-461.

(22) Legrand, L.; Schaetzle, O.; de Kler, R. C. F.; Hamelers, H. V. M. Solvent-Free $\mathrm{CO}_{2}$ Capture Using Membrane Capacitive Deionization. Environ. Sci. Technol. 2018, 52, 9478-9485. 
(23) Legrand, L.; Shu, Q.; Tedesco, M.; Dykstra, J. E.; Hamelers, H. $\mathrm{V}$. M. Role of ion exchange membranes and capacitive electrodes in membrane capacitive deionization (MCDI) for $\mathrm{CO}_{2}$ capture. $J$. Colloid Interface Sci. 2020, 564, 478-490.

(24) Eisaman, M. D.; Alvarado, L.; Larner, D.; Wang, P.; Garg, B.; Littau, K. A. $\mathrm{CO}_{2}$ separation using bipolar membrane electrodialysis. Energy Environ. Sci. 2011, 4, 1319-1328.

(25) Eisaman, M. D.; Alvarado, L.; Larner, D.; Wang, P.; Littau, K. A. $\mathrm{CO}_{2}$ desorption using high-pressure bipolar membrane electrodialysis. Energy Environ. Sci. 2011, 4, 4031-4037.

(26) Stucki, S.; Schuler, A.; Constantinescu, M. Coupled $\mathrm{CO}_{2}$ recovery from the atmosphere and water electrolysis: Feasibility of a new process for hydrogen storage. Int. J. Hydrogen Energy 1995, 20, 653-663.

(27) Rahimi, M.; Catalini, G.; Hariharan, S.; Wang, M.; Puccini, M.; Hatton, T. A. Carbon Dioxide Capture Using an Electrochemically Driven Proton Concentration Process. Cell Rep. Phys. Sci. 2020, No. 100033.

(28) Sabatino, F.; Mehta, M.; Grimm, A.; Gazzani, M.; Gallucci, F.; Kramer, G. J.; van Sint Annaland, M. Evaluation of a Direct Air Capture Process Combining Wet Scrubbing and Bipolar Membrane Electrodialysis. Ind. Eng. Chem. Res. 2020, 59, 7007-7020.

(29) Kuntke, P.; Rodríguez Arredondo, M.; Widyakristi, L.; ter Heijne, A.; Sleutels, T. H. J. A.; Hamelers, H. V. M.; Buisman, C. J. N. Hydrogen Gas Recycling for Energy Efficient Ammonia Recovery in Electrochemical Systems. Environ. Sci. Technol. 2017, 51, 3110-3116.

(30) Kuntke, P.; Rodrigues, M.; Sleutels, T.; Saakes, M.; Hamelers, H. V. M.; Buisman, C. J. N. Energy-Efficient Ammonia Recovery in an Up-Scaled Hydrogen Gas Recycling Electrochemical System. ACS Sustainable Chem. Eng. 2018, 6, 7638-7644.

(31) Sander, R. Compilation of Henry's law constants (version 4.0) for water as solvent. Atmos. Chem. Phys. 2015, 15, 4399-4981.

(32) Wang, X.; Conway, W.; Burns, R.; McCann, N.; Maeder, M. Comprehensive Study of the Hydration and Dehydration Reactions of Carbon Dioxide in Aqueous Solution. J. Phys. Chem. A 2010, 114, 1734-1740.

(33) Arredondo, M. R.; Kuntke, P.; Ter Heijne, A.; Hamelers, H. V.; Buisman, C. J. Load ratio determines the ammonia recovery and energy input of an electrochemical system. Water Res. 2017, 111, 330-337.

(34) Paz-Garcia, J. M.; Schaetzle, O.; Biesheuvel, P. M.; Hamelers, H. V. M. Energy from $\mathrm{CO}_{2}$ using capacitive electrodes - Theoretical outline and calculation of open circuit voltage. J. Colloid Interface Sci. 2014, 418, 200-207.

(35) Bui, M.; Adjiman, C. S.; Bardow, A.; Anthony, E. J.; Boston, A.; Brown, S.; Fennell, P. S.; Fuss, S.; Galindo, A.; Hackett, L. A.; Hallett, J. P.; Herzog, H. J.; Jackson, G.; Kemper, J.; Krevor, S.; Maitland, G. C.; Matuszewski, M.; Metcalfe, I. S.; Petit, C.; Puxty, G.; Reimer, J.; Reiner, D. M.; Rubin, E. S.; Scott, S. A.; Shah, N.; Smit, B.; Trusler, J. P. M.; Webley, P.; Wilcox, J.; Mac Dowell, N. Carbon capture and storage (CCS): the way forward. Energy Environ. Sci. 2018, 11, 10621176.

(36) Fasihi, M.; Efimova, O.; Breyer, C. Techno-economic assessment of $\mathrm{CO}_{2}$ direct air capture plants. J. Cleaner Prod. 2019, 224, 957-980. 